\title{
HYDRODYNAMIC MODEL OF THE NEW WATERWAY THROUGH THE VISTULA SPIT
}

\author{
Michał Szydłowski \\ Tomasz Kolerski \\ Gdańsk University of Technology, Poland
}

\begin{abstract}
The decision to build a new waterway (strait) in the Polish part of the Vistula Spit was made in 2017. The new connection between the Gulf of Gdansk and the Vistula Lagoon is planned as an artificial navigable channel with a lock and a small port. During storm surges and wind tides in the gulf or in the lagoon, sluicing will be required for vessels to tackle the Vistula Spit. This procedure does not require significant water flow through the channel in normal conditions. However, in the case of a lock failure or in the case of controlled opening of the gate to increase water exchange in the lagoon or to reduce flood risk in the Vistula Lagoon, high flow rates may occur in the navigable channel and in the neighboring port basin. In order to inves-tigate the hydraulic conditions in such extraordinary situations, numerical modeling of the hydrodynamics during water damming in the gulf or in the lagoon is performed. To analyze the hydrodynamics of the artificial connection between the sea and the lagoon during periods of high water stages, mathematical modeling is required. This paper presents the shallow water equations (SWE) model adapted to simulate the flow through the port basin and the navigable channel. The calcula-tions allowed the relation between the water head and the capacity of the navigable channel to be found, as well as to analyze circulations which may occur in the port basin.
\end{abstract}

Keywords: navigable canal,waterway,Vistula Spit,Vistula Lagoon, hydrodynamics, mathematical modeling

\section{INTRODUCTION}

The Vistula Lagoon is located in the east part of the Gulf of Gdańsk (Baltic Sea) (Fig. 1). The lagoon represents a transboundary water body divided into two parts by the country border between Poland and Russia. The length of the lagoon is $90.7 \mathrm{~km}$, and its width varies from almost $6 \mathrm{~km}$ up to $13 \mathrm{~km}$. The lagoon is a shallow basin with a mean depth of about $2.75 \mathrm{~m}$. It is separated from the Gulf of Gdańsk by the Vistula Spit. The length of the spit is $65 \mathrm{~km}$. The only connection between the Vistula Lagoon and the Baltic Sea is through the Strait of Baltiysk (located in the Russian part of the lagoon), which is $2 \mathrm{~km}$ long, $440 \mathrm{~m}$ wide and approximately $8.8 \mathrm{~m}$ deep. The total area of the lagoon measures $838 \mathrm{~km} 2$, of which $472.5 \mathrm{~km} 2$ belongs to Russia. The shoreline is $270 \mathrm{~km}$ long [1] [2].

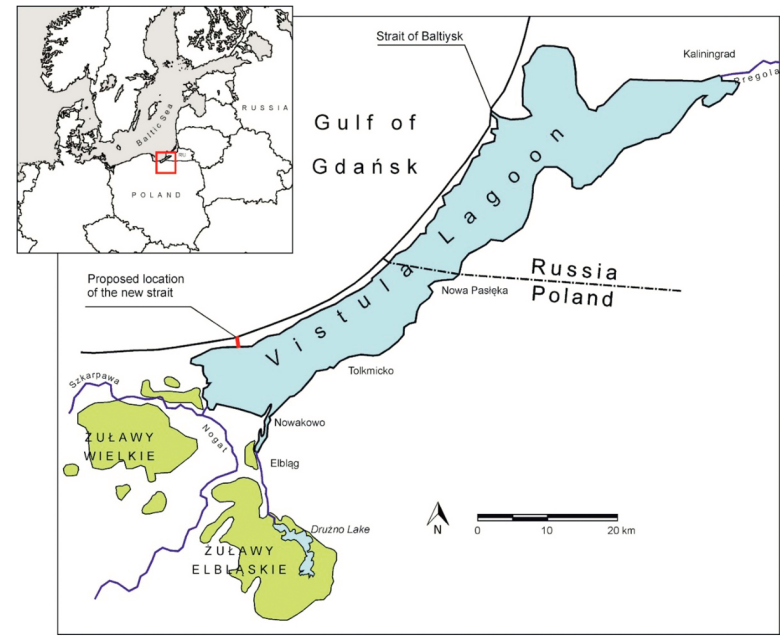

Fig. 1. Location of the Vistula Lagoon and the new strait 
Hydraulic conditions in the Vistula Lagoon are usually the result of variations in the sea level in the Gulf of Gdańsk and the wind action on the water surface of the lagoon [1] [3] [4]. When the water stage of the Gulf of Gdańsk rises, a difference in sea level occurs in relation to the lagoon. This results in a strong water current through the Strait of Baltiysk directed into the lagoon. A decrease in the water table in the Baltic Sea causes the lagoon water to flow into the sea, creating a strong current in the strait in the opposite direction. The long-lasting damming of water in the southern part of the lagoon can be a cause of flood risk for the lowland areas of Żuławy Elbląskie [5] [6].

Currently, the project [7] of a new strait connecting the Baltic Sea with the Vistula Lagoon is in progress. Similar investments are known in the world [8], but each of them is different and requires individual political, economic and technical analysis. This work focuses solely on the hydraulic aspects of the issue. Over the years, the idea of a Polish strait was often revived [9] [10], and the final decision to build this hydro-engineering structure was made in 2017. Nowy Świat was chosen as the location (Fig. 1) for the new navigable channel. The aim of the project is to significantly shorten the waterway from the Polish port of Elbląg to the Baltic Sea. Moreover, due to the possibility of opening the channel for outflowing water in case of the accumulation and rise of water in the southern part of the Vistula Lagoon, the flood risk for the polders of the lowland areas of Żuławy Elbląskie can potentially be limited [11]. This problem was analyzed in detail in [5], but in this paper only the local impact of the investment on water flow dynamics around the new artificial strait is considered. Additionally, the opening of the channel can be used to force the flow from the gulf to the lagoon to exchange the water in the basin and to improve the quality of water in the Polish part of the lagoon.

The new strait project is currently being implemented. The basic elements of the waterway include the construction of a navigable channel through the Vistula Spit, the construction of a fairway from the mouth of the Elbląg Bay to the channel, an artificial island in the Vistula Lagoon, breakwaters at the entrances to the navigable channel, and a small port in the Gulf of Gdańsk. Under normal conditions, the water flow through the port and the navigable channel will be controlled and limited by the operation of a lock located in the navigable channel. In accordance with the project, the lock will only be open for navigational purposes, and thus the flow exchange will be limited to the amount filled in the lock chamber. However, in exceptional situations, such as a lock failure, damage to (breaking of) the gates, the emergency opening of the gates during flooding at Żuławy Elbląskie or controlled opening to exchange the water in the lagoon, high discharges of water flow can be expected in the navigable channel. The flow dynamics (flow rate, velocity, profile of the water table, direction of currents) will depend on the actual difference in water levels in the gulf and in the lagoon and on the geometry (shape) of the breakwaters, the navigable channel and the lock.

The main purpose of the work is to find the hydraulic characteristics of the new navigable channel together with some hydro-engineering structures like the breakwaters and port basin. The basic characteristics should include elements such as possible flow rates and velocities in the navigable channel, the water surface profile along the channel and the structure of water circulations in the port basin. In order to investigate the dynamics of the water flow through the port, the navigable channel and at the areas near the breakwaters located in the Gulf of Gdańsk and in the Vistula Lagoon, numerical simulations are needed. This paper presents the mathematical modeling of the hydrodynamics of the artificial strait in the Vistula Spit, based on the solution of shallow water equations (SWE) by the finite volume method (FVM) [12] considering the different water levels in the Gulf of Gdańsk and the Vistula Lagoon.

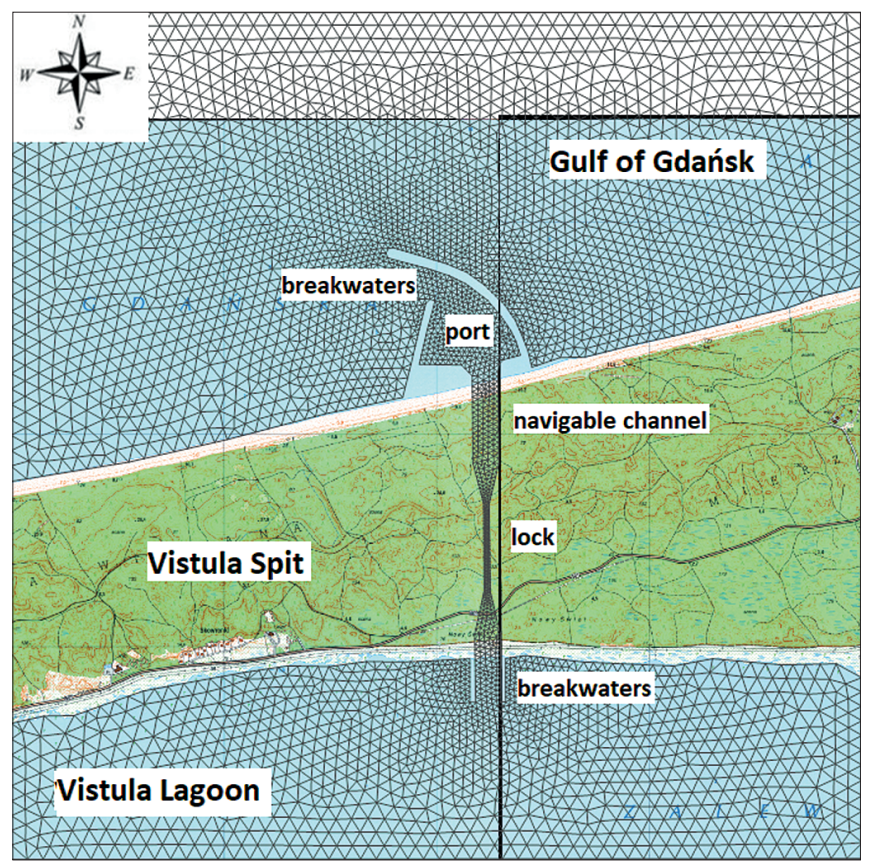

Fig. 2. Schematic geometry of the new waterway and numerical mesh of the flow area (image prepared by the authors on the basis of the https://www.geoportal.gov.pl/ map and waterway project [7], area $4 \mathrm{~km} \times 4 \mathrm{~km}$ without scale)

\section{MATERIALS AND METHODS}

\section{DATA}

The new waterway design was conceived in 2017 by two companies - Mosty Gdańsk Ltd. and Projmors Biuro Projektów Budownictwa Morski Ltd. [7]. Full information about the project is public and can be found on https://www. umgdy.gov.pl/. All data necessary to perform the calculations were taken from this project.

\section{STUDY AREA}

Nowy Świat and its surroundings was the chosen location for the channel (Fig. 1 and Fig. 2). The course of the navigable channel is along a North-South direction. The approximate location of the axis of the channel, in the Poland CS92 system, 
is at coordinate $\mathrm{x}=520235$. The length of the channel from the northern shoreline to the end of the southern breakwaters is $1,515 \mathrm{~m}$. The channel has a basic width of $90 \mathrm{~m}$, and it narrows to $25 \mathrm{~m}$ in the lock area (420 m long). The channel stretches from coordinate $y=720760$ (Vistula Lagoon) to $y=722275$ (Gulf of Gdańsk). The northern breakwater of the port on the Gulf of Gdańsk reaches the coordinate $y=722880$. The flat bottom of the channel and the port is located at $-5.0 \mathrm{~m}$ above sea level.

\section{HYDRAULIC ASPECTS OF THE NEW STRAIT}

The new strait (Fig. 2) in the land area is composed of an artificial open channel of rectangular cross-section and a constriction (local restriction of the channel cross-section) in the lock segment. The one-dimensional hydraulic theory of flow through such a non-prismatic channel was described by Chow [13]. The impact of the constriction on the water flow depends mainly on the channel geometry, the flow rate and the regime of flow, which can be sub- or supercritical. In channels with mild slopes, the flow is usually subcritical. If the narrowing is local (short), the obstruction induces a backwater effect that may extend over a long distance upstream, and the flow is subcritical along the constriction and the downstream channel. But if the constriction is sufficiently long, it forms a narrow channel. This can mean that the minimum of specificenergy rises in the constriction section corresponds to the critical water stage. Such a situation results in a supercritical flow occurring in the narrow part of the channel, which can be returned to normal conditions (subcritical flow) by the formation of a hydraulic jump.

Different effects can be observed in steep slope channels for supercritical flow conditions. When a flow is supercritical, the constriction disturbs only the water surface that is adjacent to the upstream side of the constriction. If the constriction is local, only the water surface close to the constriction is disturbed and the effect does not extend farther upstream. If the constriction is long, it can make the depth upstream of the constriction greater than the critical depth due to the need to increase the specific energy upstream of the obstruction. This makes the flow subcritical in this channel section and requires the formation of a hydraulic jump.

The theoretical one-dimensional description of the influence of the channel constriction provides only information about averaged flow parameters along the channel. In the current study, a more complex analysis of the flow structure in the navigable channel, lock, port basin and flow area around the breakwaters is proposed. Therefore, multidimensional hydrodynamics modeling must be implemented to solve the problem. In the case of the designed navigable channel, the bottom is horizontal, so the flow is determined only by the hydraulic conditions (water stages) in the Gulf of Gdańsk and in the Vistula Lagoon. The flow parameters along the waterway depend on the actual difference (water head) between the water surface elevation in the gulf and the lagoon. In this study, numerical simulations were performed for various water heads, which cover the possible hydrological conditions observed in this region. In the vicinity of the new navigable channel, SW winds can cause a rise in the water level in the Gulf of Gdańsk and in the Vistula Lagoon of even $0.8 \mathrm{~m}$ asl. However, NE winds in particular cause a dangerous water level rise in the southern part of the Vistula Lagoon. For long periods of strong NE winds, a rise in the water level exceeding $+1.0 \mathrm{~m}$ and in extremes reaching $+1.5 \mathrm{~m}$ asl can be observed [1] [5].

\section{MATHEMATICAL MODEL AND SOLUTION METHOD}

The problem of how complex a model is needed to mathematically describe the hydrodynamics depends on the aim of the numerical simulation. Simplified models [14] [15] can be applied in cases of horizontal water flow with limited water stage changes. If a strong variation in flow parameters is expected, fully hydrodynamic models should be used [16]. Many mathematical models of the Vistula Lagoon have been developed over the last decades, including two-dimensional (2D) hydrodynamic models [5] [4] [17], 2D models composed of hydrodynamics, water quality and eutrophication models [18] [19] [20], and recently developed three-dimensional models used for sediment transport and migration [21] [22]. However, the complex hydrodynamics inside the planned waterway through the Vistula Spit have not been simulated so far.

In the current study, the water flow is investigated by applying the SWE two-dimensional hydrodynamic model. The system of shallow water equations in conservation form [23] can be written as:

$$
\frac{\partial \mathbf{U}}{\partial t}+\frac{\partial \mathbf{E}}{\partial x}+\frac{\partial \mathbf{G}}{\partial y}+\mathbf{S}=0
$$

where

$$
\begin{gathered}
\mathbf{U}=\left[\begin{array}{l}
h \\
u h \\
v h
\end{array}\right], \quad \mathbf{S}=\left[\begin{array}{l}
0 \\
-g h\left(S_{o x}-S_{f x}\right) \\
-g h\left(S_{o y}-S_{f y}\right)
\end{array}\right] \\
\mathbf{E}=\left[\begin{array}{l}
u h \\
u^{2} h+0.5 g h^{2} \\
u v h
\end{array}\right], \quad \mathbf{G}=\left[\begin{array}{l}
v h \\
u v h \\
v^{2} h+0.5 g h^{2}
\end{array}\right]
\end{gathered}
$$

In this system of equations, $h$ represents water depth, $u$ and $v$ are the depth-averaged components of velocity in $x$ and $y$ directions, respectively, $S_{o x}$ and $S_{o y}$ denote the bed slope terms, $S_{f x}$ and $S_{f y}$ are the bottom friction terms defined by the Manning formula [13], and $g$ is the acceleration due to gravity. Equation (1) can be written in another form:

$$
\frac{\partial \mathbf{U}}{\partial t}+\operatorname{div} \mathbf{F}+\mathbf{S}=0
$$

where, assuming unit vector $\mathbf{n}=\left(n_{x}, n_{y}\right)^{\mathrm{T}}$, the vector $\mathbf{F}$ is defined as $\mathbf{F n}=\mathbf{E} n_{x}+\mathbf{G} n_{y}$. 
In order to integrate the SWE in space using the finite volume method, the calculation domain is discretized into set of triangular cells (Fig. 3).

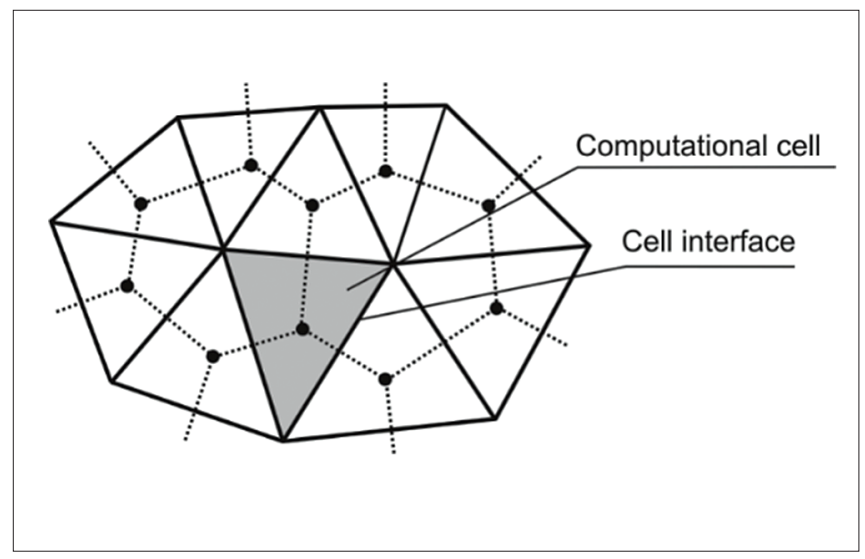

Fig. 3. Triangular computational cells for FVM

After the integration and substitution of integrals by corresponding sums, equation (3) can be rewritten as

$$
\frac{\partial \mathbf{U}_{i}}{\partial t} \Delta A_{i}+\sum_{r=1}^{3}\left(\mathbf{F}_{r} \mathbf{n}_{r}\right) \Delta L_{r}+\sum_{r=1}^{3} \mathbf{S}_{r} \Delta A_{r}=0
$$

where $\mathbf{F}_{\mathrm{r}}$ is the numerical flux of mass or momentum, and $\Delta L_{r}$ represents the cell-interface length. $\mathbf{S}_{\mathrm{r}}$ and $\Delta A_{r}$ are the components of source terms and the area of cell $i$ assigned to the $r^{\text {th }}$ cell-interface. In order to calculate the fluxes $\mathbf{F}_{r}$, the solution of the approximated Riemann problem was used. A full description of the method was presented in [12]. The numerical algorithm was complemented by a two-stage explicit scheme of time integration. The model had already been verified for the rapidly varied free surface flow by a comparison of the computed results with measurements carried out in an experimental channel at the hydraulic lab [24] [25] [26]. The model was also applied to simulate some unique case studies, such as water flow in artificial channels like slides [24] and whitewater courses [27], as well as to investigate some field problems like urban and catastrophic floods [16] [28] and river flows influenced by hydro-engineering structures [29]. Reliable results of the performed simulations confirmed the possibility of using the developed model for a numerical simulation of flow through the designed elements of the waterway, i.e. the breakwaters, port basin, and navigable channel and lock.

\section{NUMERICAL SIMULATIONS AND DISCUSSION OF THE RESULTS}

In order to simulate two-dimensional water flow in the area of the Gulf of Gdańsk, the Vistula Lagoon and the waterway through the Vistula Spit using FVM, the real geometry of the water area had to be transformed into a numerical mesh. Because only the local problem of flow in the waterway is considered in this study, the computational domain is limited to a $16 \mathrm{~km}^{2}$ square area. The $4 \mathrm{~km} \times 4 \mathrm{~km}$ flow domain, containing parts of the Gulf of Gdańsk and the Vistula Lagoon, was covered by a mesh of triangles composed of 8,312 computational cells (Fig. 2). The lengths of the sides of the triangles were variable in a range from $5 \mathrm{~m}$ in the lock segment, $25 \mathrm{~m}$ in the navigable channel, and up to $75 \mathrm{~m}$ at the open boundaries of the gulf and the lagoon.

Boundary conditions were imposed in accordance with the geometry of the flow area. The vertical walls of the navigable channel and lock were treated as closed boundaries, and the free-slip condition was enforced there. In the same way (as the land boundaries), the breakwaters, the quays and the shoreline were represented in the numerical model of the waterway. As the model domain was extended into the Gulf of Gdańsk and the Vistula Lagoon, the open (water) boundaries were located there.

The goal of performing the numerical simulations was to determine the basic flow characteristics (current direction, flow rate and velocity, water surface profile) in a hypothetically open navigable channel for specified conditions in the Gulf of Gdańsk and the Vistula Lagoon. Steady conditions were assumed in both basins. They were forced by constant water stages at the open boundaries of the flow area. It was assumed that in each simulation the lower elevation of the water surface corresponds to the average sea state $(0.0 \mathrm{~m}$ asl $)$. The values of $0.05,0.10,0.25,0.50,0.75$ and $1.0 \mathrm{~m}$ were selected as examples of the difference in the water stages in the gulf and the lagoon.

Each flow simulation was performed starting from the hydrostatic state, assuming that the closed lock gate separates two water bodies, each with a different (assumed) elevation of the water surface. Then the gate was fully opened, which allowed water to flow through the channel in a direction depending on the initial position of the water surface. The calculations were carried out for permanent boundary conditions, forcing the initial elevations of the water surface at the open boundaries (gulf and lagoon). At the same time, the free flow of water across these borders was ensured. The constant-in-time water surface elevations at the gulf and the lagoon allowed a steady state to be reached, which was the final solution.

The two-dimensional flow modeling allowed the velocity field in the area of the navigable channel to be mapped. Figures 4 and 5 show the distribution of velocity vector module for the largest assumed difference in water levels $(1.0 \mathrm{~m})$, respectively for the flow from the Gulf of Gdańsk to the Vistula Lagoon and in the opposite direction. The navigable channel hydraulics, created under such flow conditions, resemble the flow in a Venturi channel [13]. There is a strong increase in the flow velocity in the narrow part of the channel (lock), which, regardless of the flow direction, reaches almost $5 \mathrm{~m} / \mathrm{s}$. 


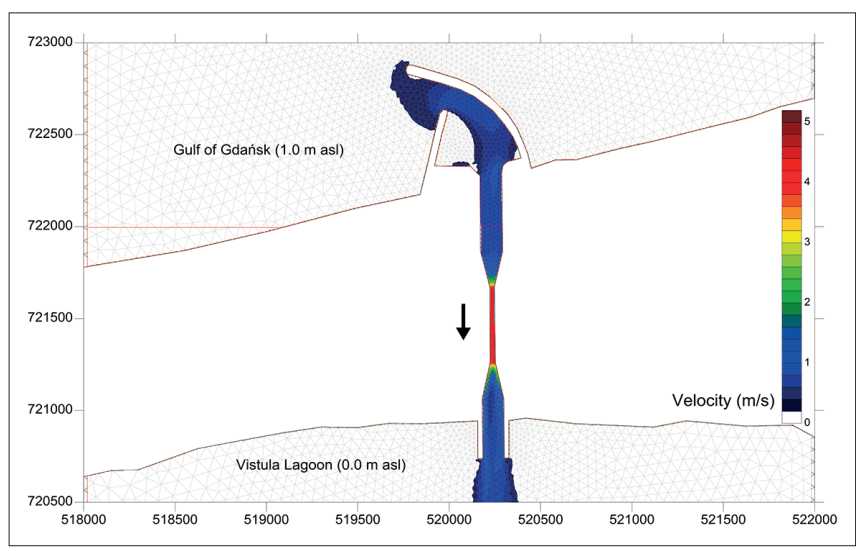

Fig. 4. Velocity vector module - flow direction from the Gulf of Gdańsk to the Vistula Lagoon

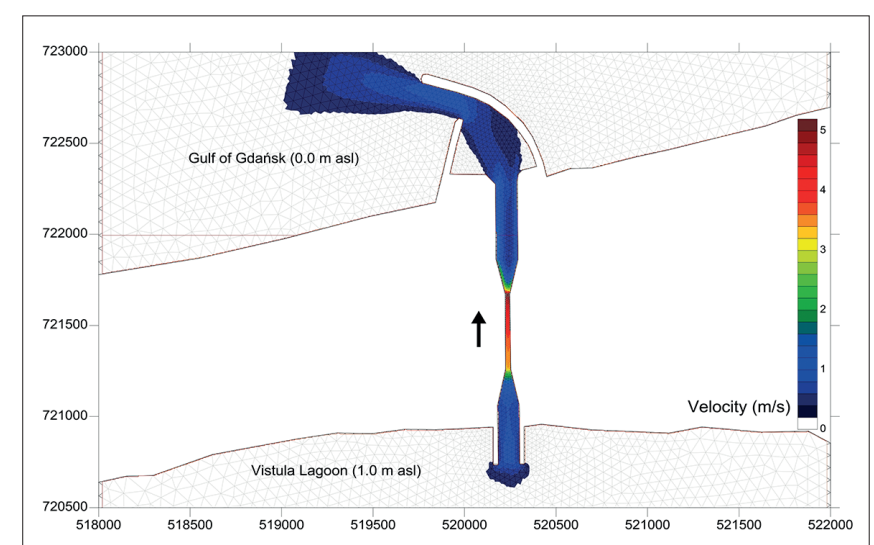

Fig. 5. Velocity vector module - flow direction from the Vistula Lagoon to the Gulf of Gdan'sk

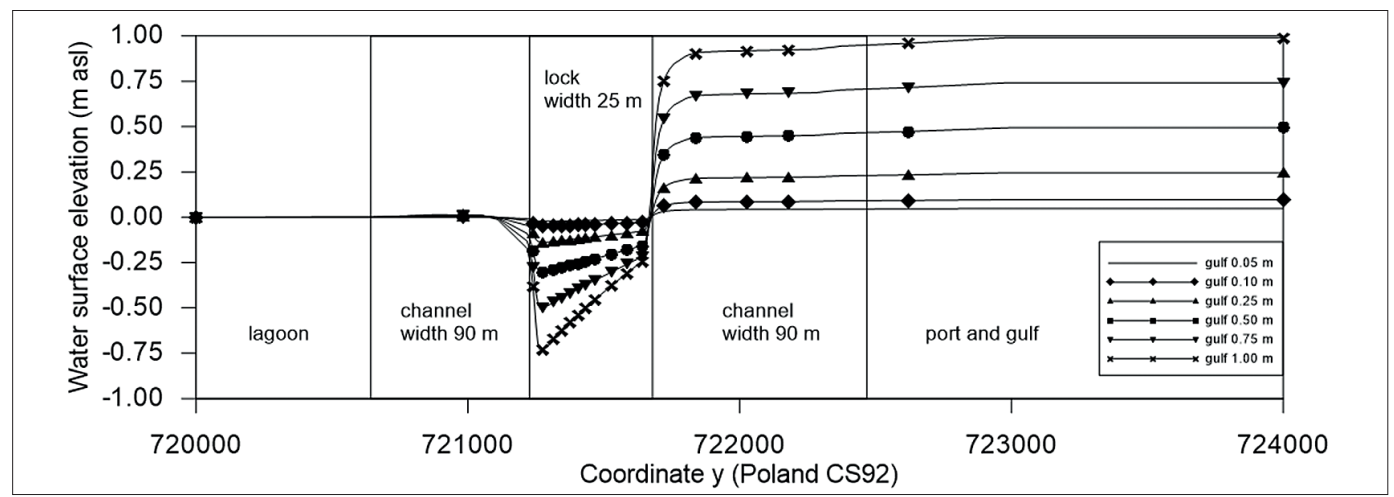

Fig. 6. Profiles of the water surface along the axis of the navigable channel (90 $\mathrm{m}$ wide) and lock ( $25 \mathrm{~m}$ wide) during the flow from the Gulf of Gdansk to the Vistula Lagoon

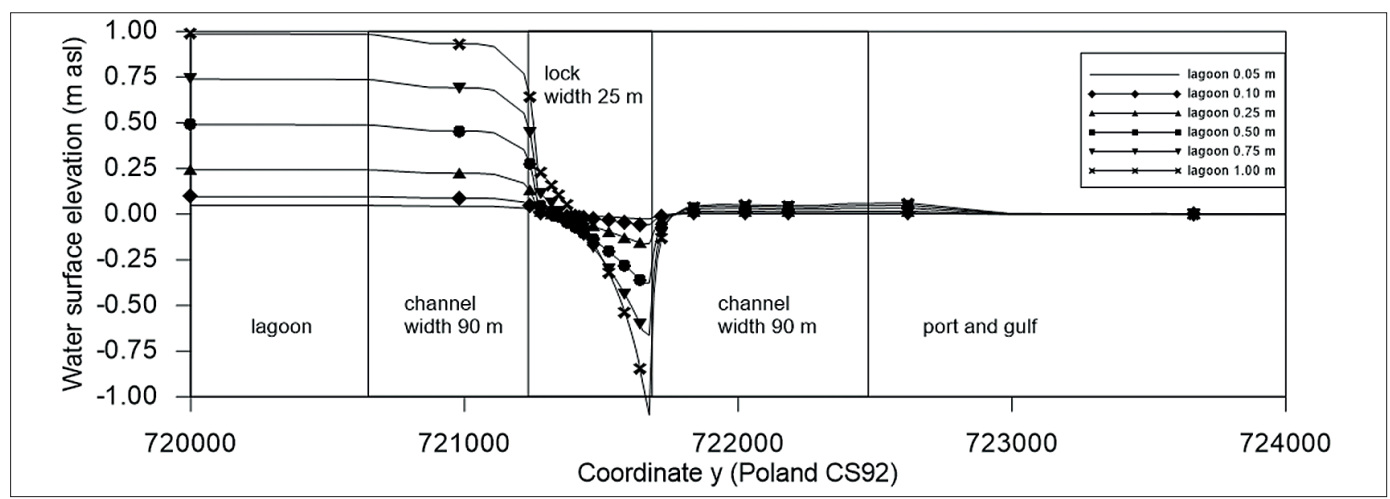

Fig. 7. Profiles of the water surface along the axis of the navigable channel ( $90 \mathrm{~m}$ wide) and lock (25 $\mathrm{m}$ wide) during the flow from the Vistula Lagoon to the Gulf of Gdańsk

There is a significant decrease in the water surface level at the same place in the lock. Figures 6 and 7 show the $4 \mathrm{~km}$ long water surface profiles along the coordinate $\mathrm{x}=520235$ (navigable channel axis). The drawings show the basic section of the channel, where the channel is $90 \mathrm{~m}$ wide, and the channel constriction (lock), which is $25 \mathrm{~m}$ wide. The water table elevation in this region reaches a level below the initial position of the water surface. Such a hydraulic phenomenon is often observed for flows through channel constrictions [13].

As can be seen in the charts, the elevation of the water surface along the narrow part of the channel, in the case of the largest difference of water levels in the gulf and the lagoon, is significantly reduced, by a maximum of about $0.75 \mathrm{~m}$, when water flows from the gulf to the lagoon, and by over $1.0 \mathrm{~m}$ for the opposite flow direction. This is accompanied by a significant increase in the flow velocity, as seen in Figs. 4 and 5. If smaller differences in water levels exist in both basins, the water surface depression in the lock is also relatively smaller.

Despite the strong depression in the water surface and the considerable increase in velocity in the navigable channel and the lock, a supercritical flow was not observed there in the performed simulations and no hydraulic jump was formed in the channel. However, the flow was almost critical (with the Froude number [13] close to unity) when the largest difference in water surface levels was modeled. 


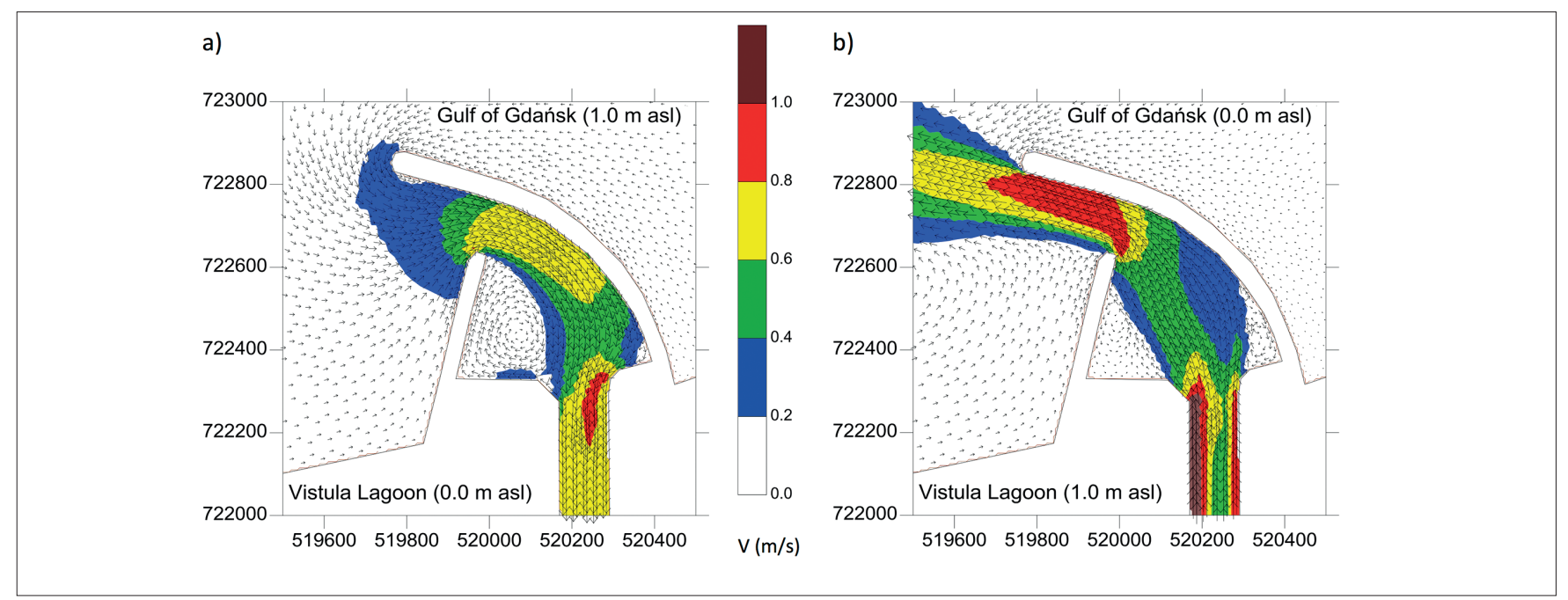

Fig. 8. The velocity vectors in the area of the port in the Gulf of Gdan'sk forced by the flow from the Gulf of Gdan'sk to the Vistula Lagoon (a) and in the opposite direction (b)

Details of the spatial distribution of the velocity field and the current directions can be investigated using the simulation results. Figure 8 shows the velocity vectors in the area of the port in the Gulf of Gdańsk for two flow directions. In the case of flow from the gulf to the lagoon (Fig. 8a), the velocities increase between the western and northern breakwaters. In the area of the western breakwater and the southern quay, a single circulation of low velocity is formed filling the entire area, while the mainstream runs along the northeastern breakwater.

In the case of flow from the lagoon to the gulf (Fig. 8b), just near the channel outlet to the port basin, two circulations are formed at both breakwaters, and the mainstream is located in the middle of the port basin. Due to local stream expansion, the velocity in the pool decreases slightly to increase again in the narrow area between the breakwater heads.
As can be seen from the results, for both flow directions, strong currents and large eddies may occur in the port basin. Such a situation may be dangerous and undesirable for all vessels in the waterway and ships anchoring at the quays.

Finally, the numerical simulations allowed the values of the flow rates in the navigable channel to be determined for the adopted range of water stages. The calculated results, obtained for the assumed water heads (differences in water surface elevation in the gulf and the lagoon), were collected in Tables 1 and 2. Figures $9 \mathrm{a}$ and $9 \mathrm{~b}$ show the flow rate curves (relation between the water head and flow rate) respectively in the case of flow from the gulf to the lagoon and in the opposite direction.

Regardless of the direction of flow, the flow rate curves are similar to each other. Some small discrepancies in the

Tab. 1. Hydraulic parameters of the navigable channel for the flow from the Gulf of Gdan'sk to the Vistula Lagoon (water level in the lagoon $0.0 \mathrm{~m}$ asl)

\begin{tabular}{|c|c|c|c|c|}
\hline $\begin{array}{c}\text { Water level in the gulf } \\
(\mathrm{m} \text { asl })\end{array}$ & $\begin{array}{c}\text { Maximum velocity } \\
(\mathrm{m} / \mathrm{s})\end{array}$ & $\begin{array}{c}\text { Minimum depth } \\
(\mathrm{m})\end{array}$ & $\begin{array}{c}\text { Flow rate } \\
\left(\mathrm{m}^{3} / \mathrm{s}\right)\end{array}$ & $\begin{array}{c}\text { Froude number } \\
\text { Fr }(-)\end{array}$ \\
\hline 0.05 & 0.92 & 4.99 & 114.77 & 0.13 \\
\hline 0.10 & 1.33 & 4.97 & 165.25 & 0.19 \\
\hline 0.25 & 2.15 & 4.92 & 264.45 & 0.31 \\
\hline 0.50 & 3.06 & 4.86 & 371.79 & 0.44 \\
\hline 0.75 & 3.75 & 4.79 & 449.06 & 0.55 \\
\hline 1.00 & 4.34 & 4.27 & 463.30 & 0.67 \\
\hline
\end{tabular}

Tab. 2. Hydraulic parameters of the navigable channel for the flow from the Vistula Lagoon to the Gulf of Gdańsk (water level in the gulf $0.0 \mathrm{~m}$ asl)

\begin{tabular}{|c|c|c|c|c|}
\hline $\begin{array}{c}\text { Water level in the lagoon } \\
(\mathrm{m} \text { asl })\end{array}$ & $\begin{array}{c}\text { Maximum velocity } \\
(\mathrm{m} / \mathrm{s})\end{array}$ & $\begin{array}{c}\text { Minimum depth } \\
(\mathrm{m})\end{array}$ & $\begin{array}{c}\text { Flow rate } \\
\left(\mathrm{m}^{3} / \mathrm{s}\right)\end{array}$ & $\begin{array}{c}\text { Froude number } \\
\text { Fr }(-)\end{array}$ \\
\hline 0.05 & 0.91 & 4.97 & 113.07 & 0.13 \\
\hline 0.10 & 1.32 & 4.94 & 163.02 & 0.19 \\
\hline 0.25 & 2.16 & 4.83 & 260.82 & 0.31 \\
\hline 0.50 & 3.05 & 4.62 & 352.28 & 0.45 \\
\hline 0.75 & 4.10 & 4.36 & 446.90 & 0.63 \\
\hline 1.00 & 5.01 & 3.90 & 488.48 & 0.81 \\
\hline
\end{tabular}




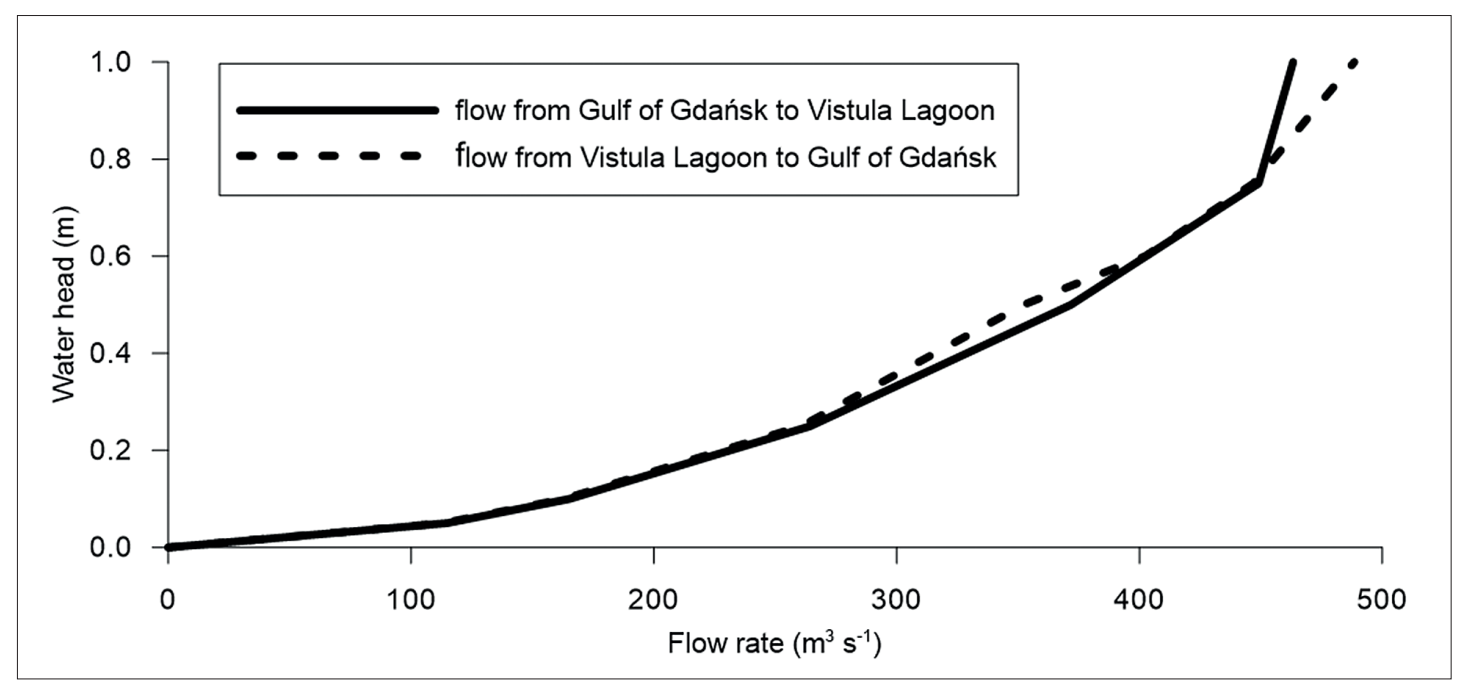

Fig. 9. Flow rate curves for the flow in the navigable channel from the Gulf of Gdansk to the Vistula Lagoon and in the opposite direction

relations are the result of differences in the channel geometry in the northern and southern part of the waterway. The shape of the breakwaters at both channel ends causes hydraulic losses, depending on the flow direction, so different discharges are observed for the same water head.

It can be found that only a $5 \mathrm{~cm}$ water stage difference between the Gulf of Gdańsk and the Vistula Lagoon can cause a flow with the maximum velocity reaching $1 \mathrm{~m} / \mathrm{s}$ in the narrow part of the channel with a rate exceeding $100 \mathrm{~m}^{3} / \mathrm{s}$. During extreme hydrological conditions, for the highest damming in the gulf or in the lagoon $(1.0 \mathrm{~m}$ assumed in this study), the maximum velocity in the lock segment can reach $5 \mathrm{~m} / \mathrm{s}$ and the rate increases up to $500 \mathrm{~m}^{3} / \mathrm{s}$.

\section{CONCLUSIONS}

The results of the two-dimensional numerical simulations of the hydrodynamics of the new strait (waterway) through the Vistula Spit allow the following to be concluded.

- The mathematical model based on 2D SWE can be successfully applied to simulate the flow through the complex hydraulic system of a waterway composed of breakwaters, a port basin, a navigable channel and a lock.

- Assuming open lock gates, the difference in water levels in the Gulf of Gdańsk and the Vistula Lagoon (water head) will force a significant flow in the navigable channel. A significant decrease in the water level in the channel is observed, which is accompanied by an increase in the flow velocity. Such a situation can prevent the movement of vessels during extreme and exceptional situations.

- Even though a water head of $1 \mathrm{~m}$ between the gulf and the lagoon is assumed, no supercritical flow occurs in the lock, nor is a hydraulic jump formed in the navigable channel.

- For both flow directions, strong currents and circulations may occur in the port basin. Such a situation, during significant damming and the opening of the navigable channel, may be dangerous and undesirable for all vessels in the port.

- The calculations allowed the relation between the water head and the capacity of the navigable channel to be found. This can be helpful to estimate the total water exchange between the sea and the lagoon during periods when the new artificial strait is open.

\section{REFERENCES}

1. Szymkiewicz, R. Hydrodynamics of Vistula Lagoon; Warsaw, 1992.

2. Cieśliński, R. Hydrochemical variability of the ecosystem of the Gulf of Elbląg (north-eastern Poland). Baltica 2016, $29,121-132$.

3. Cieśliński, R.; Lewandowski, A. Hydrological regime of the Vistula Lagoon and the possible changes due to the construction of the waterway connecting the Vistula Bay with the Gulf of Gdansk. Inżynieria Morska i Geotechnika 2013, 69-78.

4. Chubarenko, I.P.; Chubarenko, B.V. General water dynamics of the Vistula Lagoon. Environmental and Chemical Physics 2002, 24, 213-217.

5. Szydłowski, M.; Kolerski, T.; Zima, P. Impact of the artificial strait in the Vistula Spit on the hydrodynamics of the Vistula Lagoon (Baltic Sea). Water 2019, 11, 990.

6. Szymkiewicz, R. A mathematical model of storm surge in the Vistula Lagoon, Poland. Coastal Engineering 1992, 16, 181-203.

7. Nadolny, A.; Samulak, M. Construction of a waterway connecting the Vistula Lagoon with the Bay of Gdańsk 2017. 
8. García-Oliva, M.; Pérez-Ruzafa, Á.; Umgiesser, G.; McKiver, W.; Ghezzo, M.; De Pascalis, F.; Marcos, C. Assessing the hydrodynamic response of the Mar Menor Lagoon to dredging inlets tinterventions through numerical modelling. Water 2018, 10, 959.

9. Dubrawski, R.; Zachowicz, J. Navigation channel in the Vistula Spit - Positives and negatives for the marine environment. Inżynieria Morska i Geotechnika 1997, 301-307.

10. Dembicki, E.; Jednorał, T.; Sedler, B.; Jaśkowski, J.; Zadroga, B. Navigation channel in Polish part of Vistula Sandbar. Inżynieria Morska i Geotechnika 2006, 275-286.

11. Szymkiewicz, R. Analysis of a concept of changing the hydrodynamic conditions of the Vistula Lagoon. Inżynieria Morska 1984, 258-260.

12. Toro, E.F. Riemann Solvers and Numerical Methods for Fluid Dynamics: A Practical Introduction; 3rd ed.; Springer-Verlag: Berlin Heidelberg, 2009; ISBN 978-3-540-25202-3.

13. Chow, V.T. Open-channel hydraulics; McGraw-Hill Book Company: New York, 1959;

14. Zima, P. Modeling of the two-dimensional flow caused by sea conditions and wind stresses on the example of Dead Vistula. Polish Maritime Research 2018, 25, 166-171.

15. Gąsiorowski, D. Analysis of floodplain inundation using 2D nonlinear diffusive wave equation solved with splitting technique. Acta Geophys. 2013, 61, 668-689.

16. Szydłowski, M. Mathematical modelling of flash floods in natural and urban areas. In Proceedings of the Transboundary Floods: Reducing Risks Through Flood Management; Marsalek, J., Stancalie, G., Balint, G., Eds.; Springer Netherlands, 2006; pp. 143-153.

17. Kolerski, T.; Zima, P.; Szydłowski, M. Mathematical modeling of ice thrusting on the shore of the Vistula Lagoon (Baltic Sea) and the proposed artificial island. Water 2019, 11, 2297.

18. Kwiatkowski, J.; Rasmussen, E.K.; Ezhova, E.; Chubarenko, B.V. The eutrophication model of the Vistula Lagoon. Oceanological Studies 1997, 26, 5-33.

19. Chubarenko, I.; Tchepikova, I. Modelling of man-made contribution to salinity increase into the Vistula Lagoon (Baltic Sea). Ecological Modelling 2001, 138, 87-100.

20. Ołdakowski, B.; Kwiatkowski, J. Forecast model of water quality of Vistula Lagoon. Inżynieria Morska i Geotechnika 1995.

21. Bielecka, M.; Kazmierski, J. A 3d mathematical model of Vistula Lagoon hydrodynamics - General assumptions and results of preliminary calculations; ECSA 8, Dublin, 2003; pp. 140-145.

22. Kruk, M.; Kempa, M.; Tjomsland, T.; Durand, D. The use of mathematical models to predict changes in the environment of the Vistula Lagoon. In Vistula Lagoon Natural environment and modern methods of his research project on the example of Visla; Publishing PWSZ: Elbląg, 2011; pp. 165-180.

23. LeVeque, R.J. Finite Volume Methods for Hyperbolic Problems; Cambridge University Press, 2002; ISBN 978-0-521-00924-9.

24. Burzyński, K.; Szydłowski, M. Numerical simulation of rapidly varied water flow in 'Wild River' type water slide. Archives of Hydro-Engineering and Environmental Mechanics 2003, 50, 3-23.

25. Szydłowski, M. Numerical simulation of open channel flow between bridge piers. TASK Quarterly 2011, 15, 271-282.

26. Szydłowski, M. Numerical modeling of hydrodynamics as a tool for design of the leisure and sport water structures. Acta Scientiarum Polonorum - Formatio Circumiectus 2016, $15,353-367$.

27. Szydłowski, M.; Mikos-Studnicka, P. Shallow water equations as a mathematical model of whitewater course hydrodynamics. In Recent Trends in Environmental Hydraulics; Geoplanet: Earth and Planetary Sciences; Springer Berlin Heidelberg: Berlin Heidelberg, 2020; p. accepted to publish.

28. Szydłowski, M. Application of hydrodynamics model for a case study of the Kolbudy II Reservoir Embankment hypothetical failure. In Experimental Methods in Hydraulic Research; Rowinski, P., Ed.; Geoplanet: Earth and Planetary Sciences; Springer Berlin Heidelberg: Berlin, Heidelberg, 2011; pp. 299-306 ISBN 978-3-642-17475-9.

29. Szydłowski, M.; Kolerski, T. Numerical modeling of water and ice dynamics for analysis of flow around the Kiezmark Bridge piers. In Free Surface Flows and Transport Processes; Geoplanet: Earth and Planetary Sciences; Springer Berlin Heidelberg: Berlin, Heidelberg, 2018; pp. 465-476. 


\section{CONTACT WITH THE AUTHORS}

\section{Michał Szydłowski}

e-mail:mszyd@pg.edu.pl

Gdańsk University of Technology

Faculty of Civil and Environmental Engineering

11/12 Gabriela Narutowicza Street, 80-233 Gdańsk

\section{Poland}

\section{Tomasz Kolerski}

e-mail:tomkoler@pg.gda.pl

Gdańsk University of Technology

Faculty of Civil and Environmental Engineering 11/12 Gabriela Narutowicza Street, 80-233 Gdańsk

Poland 